Universidade de Lisboa

Faculdade de Ciências

Departamento de Biologia Animal

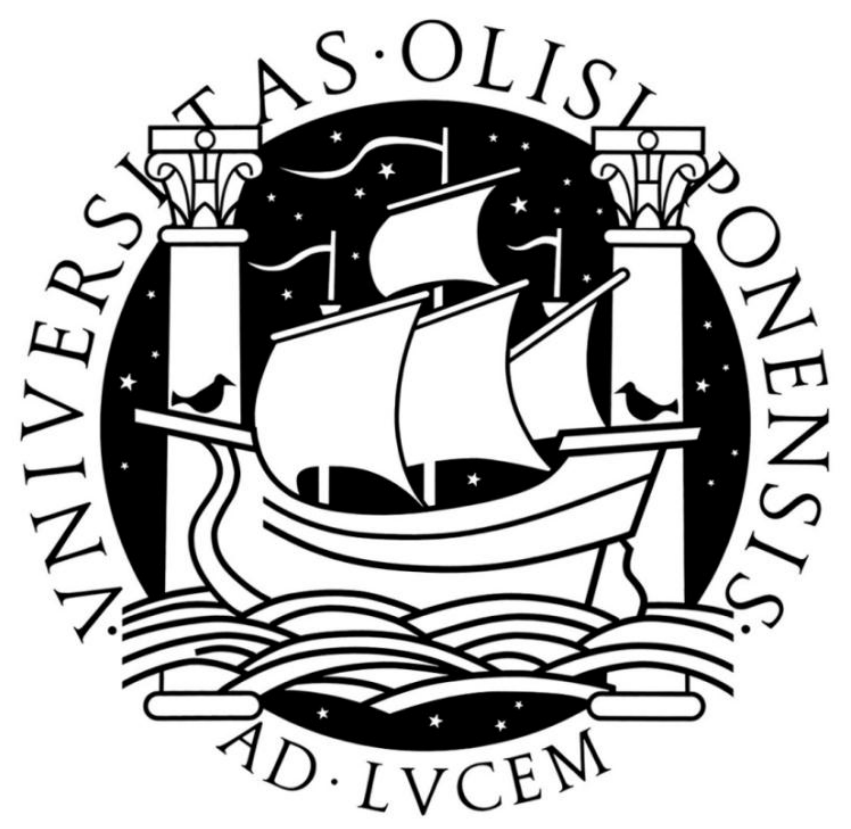

The role of agonistic sounds in male nest defence in the painted goby Pomatoschistus pictus.

Ricardo Jorge Soares Pereira

\author{
Dissertação
}

Mestrado em Ciências do Mar 
Universidade de Lisboa

Faculdade de Ciências

Departamento de Biologia Animal

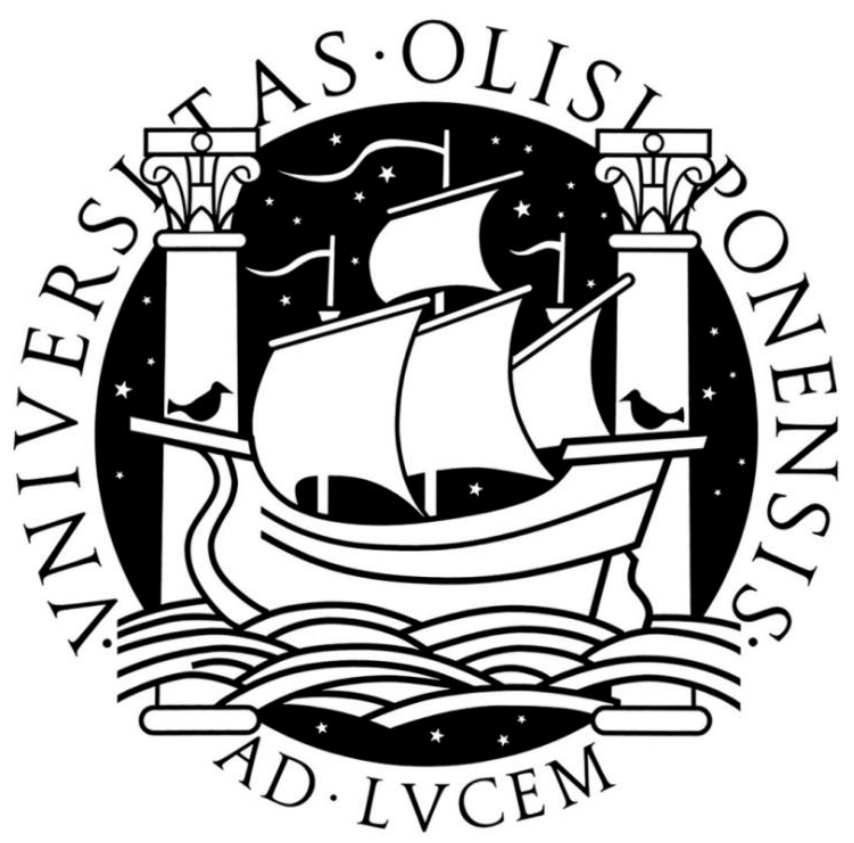

The role of agonistic sounds in male nest defence in the painted goby Pomatoschistus pictus.

Ricardo Jorge Soares Pereira

\author{
Dissertação
}

Mestrado em Ciências do Mar

Orientadores: Professor Doutor Paulo Fonseca

Doutora Maria Clara Amorim 


\section{Index}

Abstract

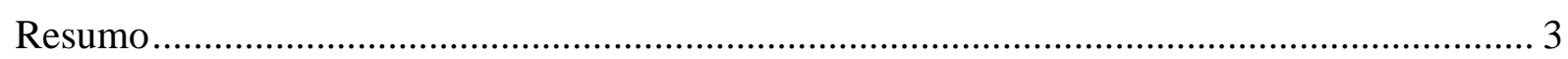

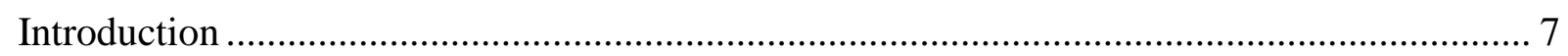

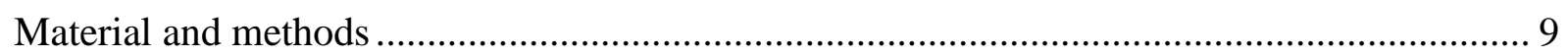

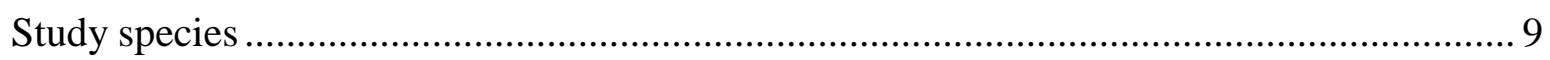

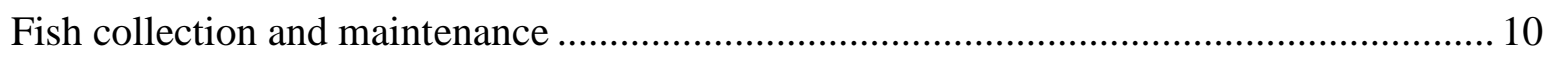

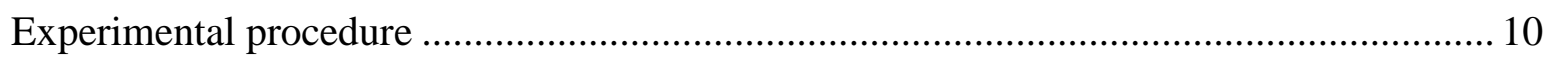

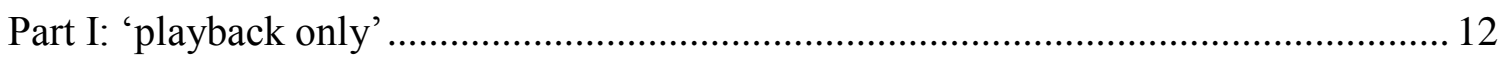

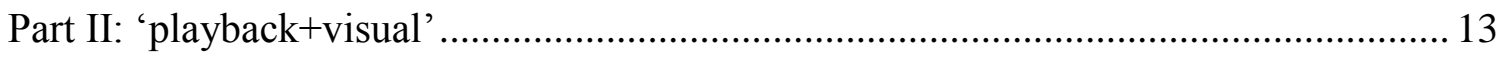

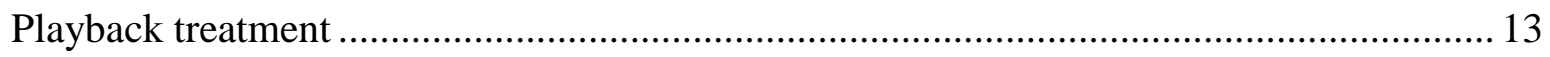

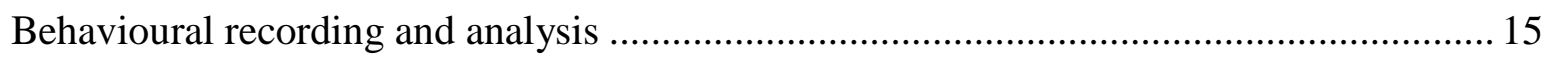

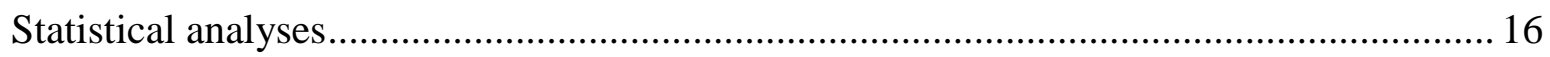

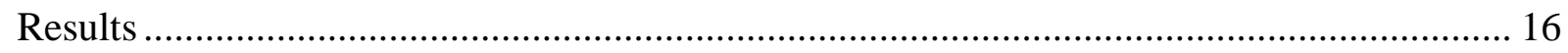

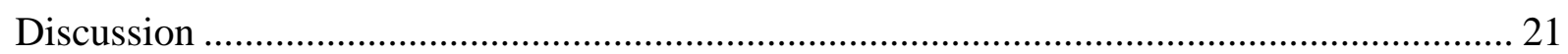

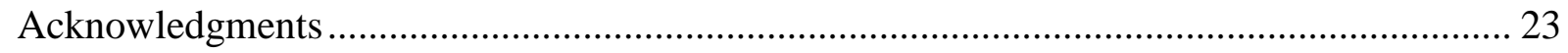

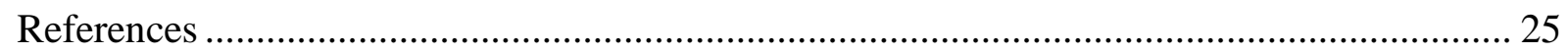




\title{
The role of agonistic sounds in male nest defence in the painted goby Pomatoschistus pictus
}

\author{
Pereira $^{1}$, R., S. Rismondo ${ }^{1}$, M. Caiano ${ }^{1}$, S. S. Pedroso ${ }^{1}$, P. J. Fonseca ${ }^{1}$, M. C. P. Amorim ${ }^{2}$
}

${ }^{1}$ Departamento de Biologia Animal e Centro de Biologia Ambiental, Faculdade de Ciências da Universidade de Lisboa. Bloco C2, Campo Grande, 1749-016 Lisboa, Portugal;

${ }^{2}$ Unidade de Investigação em Eco-Etologia, Instituto Superior de Psicologia Aplicada - Instituto Universitário, Rua Jardim do Tabaco 34, 1149-041 Lisboa, Portugal.

To Neka (what kind of cat doesn't love some gobies?) 


\section{Abstract}

Agonistic behaviour plays an important role in a species reproduction and survival. Several animals, including fish, use acoustic signals in early phases of disputes over territories or mates. Acoustic communication can be used during mutual assessment and help to avoid overt aggression, which can lead to severe body injuries or eventually to mortality. In this study we carried out playback experiments to test the function of agonistic sounds in territorial defence in a small marine goby. We measured the behaviour of individual males towards two nests placed in opposite sides of the aquarium, associated with either conspecific agonistic sounds or a control: silence or white noise. Sounds were played back interactively, i.e. a sequence of sounds was produced when the fish approached a nest. Additionally, we made similar experiments that also included visual stimuli that consisted of a conspecific male in a confinement aquarium near each nest. We registered the number of times the male approached, avoided, explored, entered and exited each nest type. In the silence vs sound treatment, males approached similarly nests associated with conspecific sounds or silent nests. However, males avoided nests associated with agonistic sounds more frequently than silent nests regardless of the presence of a nearby male. Further, males entered and exited nests associated with agonistic sounds more frequently than silent ones regardless of the absence/presence of visual stimuli. We found no significant effect of the playback treatment in any measured male behaviour when the control was white noise. The results suggest that agonistic sounds are effective in territorial defence in this species but the actual presence of a male actively guarding the nest is needed to prevent nest intrusion. Further, we can exclude the possibility that any sound may act as a deterrent in nest occupation.

Keywords: Acoustic signals, agonistic behaviour, territorial defence, 'keep-out' signal, playback experiments, teleost fish 


\section{Resumo}

Nos diferentes ecossistemas, os machos de diversas espécies entram usualmente em confronto, motivados por vários factores como a escassez de algum recurso ou a competição por território, ou mesmo pela necessidade natural de reproduzir, competindo assim pela atenção das fêmeas da mesma espécie. Estes comportamentos agonísticos estão descritos em vários animais, estando uma série deles relacionados com a produção de som. De acordo com diferentes estudos, estes podem ser emitidos em diversos contextos como a defesa do território, e consequente afastamento de possíveis adversários, ou mesmo como mecanismo de avaliação indirecta das condições físicas e de motivação do oponente. Tal estratégia é de extrema importância, uma vez que através da mesma é possível ao indivíduo evitar com que confrontos com outros machos evoluam para níveis de maior agressividade e, portanto, de maior custo energético, que se se poderiam traduzir em graves ferimentos ou mesmo na sua morte. Para além disso, a energia poupada nesses confrontos pode depois ser utilizada de forma mais rentável noutras actividades biológicas de interesse da espécie, como os rituais de acasalamento e defesa activa do ninho e crias.

Tal situação é igualmente observada nos peixes, em que a produção de som está associada a mecanismos de corte e de defesa territorial. Porém, ao contrário do que acontece nos animais terrestres e devido às diferenças do meio em que habitam, nos peixes tal fenómeno está normalmente relacionado com a interacção entre a contracção de músculos específicos e estruturas de ressonância existentes no organismo do animal, ou então em resultado da presença de estruturais corporais especializadas. A principal estratégia de produção de som nos peixes consiste na contracção de músculos sónicos contra as paredes da bexiga-natatória do animal, existindo no entanto outros mecanismos, como a fricção de barbatanas específicas ou mesmo a combinação simultânea de diferentes processos em algumas espécies. 
Ainda que se conheça a importância dos sons na sobrevivência de muitas espécies de peixes, em norma, este comportamento é combinado com outras estratégias de forma a permitir uma postura agonística mais eficaz, levando a uma maior probabilidade de sucesso na defesa do território. Assim, muitas vezes a sua produção está associada a uma série de exibições visuais, como variações nas cores do peixe ou mesmo a erecção de barbatanas específicas quando na presença de uma ameaça. Adicionalmente, tem-se conhecimento com base em estudo prévios de playbacks que, regra geral, os sons permitem uma avaliação das características dos adversários sem que haja necessidade de um confronto directo entre os animais e um possível escalar de interacções até situações de maior desgaste energético e físico, como foi referido anteriormente. Assim, entende-se que alguns factores influenciam as características dos sons produzidos pelo peixe, como sejam as suas dimensões corporais, motivação ou mesmo os níveis de hormonas que circulam no seu organismo.

Neste estudo tivemos como objectivo avaliar a importância destes sons numa espécie de peixe encontrado em águas pouco profundas junto à costa Portuguesa, Pomatoschistus pictus. A sua recolha foi realizada entre Janeiro e Abril do presente ano, durante marés-baixas, sendo posteriormente aclimatados em aquários de stock existentes no laboratório. Posteriormente, realizamos diferentes tratamentos de playback recorrendo a sons agonísticos da mesma espécie e a dois tipos de controlo - silêncio e ruído branco. Para tal usamos aquários experimentais divididos em três compartimentos de iguais dimensões, tendo colocado o macho a testar numa das divisões (central) e dois ninhos artificiais nas restantes, os quais estariam associados a diferentes tipos de estímulos sonoros emitidos através de altifalantes colocados por trás dos mesmos. Desta forma pudemos observar a existência de uma possível preferência dos machos por ninhos 'ocupados' (i.e. associados a um estímulo acústico) por oposição a ninhos desocupados (silenciosos) ou associados a um controlo sonoro (ruído 
branco). $\mathrm{O}$ acesso aos ninhos estava inicialmente bloqueado pela existência de partições laterais de plástico, que foram posteriormente removidas permitindo o acesso do peixe a todo o aquário experimental. Nestas experiências, denominadas de 'playback only', os machos foram sujeitos a dois tipos de pré-estímulo - um visual seguido de um sonoro - antes do período de teste. Durante este período os playbacks foram emitidos de forma interactiva, o que significa que sempre que o peixe se aproximou de um dos ninhos foram emitidos os três primeiros sons do estímulo sonoro respectivo. Adicionalmente, realizamos um outro tipo de experiência - 'playback+visual' - similar à referida anteriormente mas à qual associamos um estímulo visual. Desta forma, após um pré-estímulo sonoro, os machos foram expostos a dois indivíduos que se encontravam aprisionados num pequeno aquário colocado, durante o período de teste, em cada um dos compartimentos laterais junto a cada um dos ninhos. Estes recipientes eram altos o suficiente para evitar a mistura da água do macho testado com a dos machos laterais evitando-se, desta forma, qualquer tipo de interacção química entre os animais. O comportamento dos peixes foi gravado em cada sessão recorrendo-se a uma câmara de filmar, que permitiu a posterior análise individual dos diferentes comportamentos do macho em relação ao ninho ou, quando aplicável, ao estímulo visual. Assim procedeu-se à contagem do número total de aproximações, evitamentos, explorações, entradas e saídas dos ninhos ao longo do período de teste, possibilitando de seguida a análise estatística dos mesmos dados, tendo-se em conta o tipo de tratamento de playback (controlo vs som), o tipo de experiência ('playback only' ou 'playback+visual'), e a interacção entre ambos os factores. Com este estudo pudemos então observar que num primeiro tratamento de silêncio vs som os machos se aproximaram de forma significativa mais dos ninhos acústicos do que dos associados a silêncio tendo, no entanto, evitado com maior frequência o lado associado ao som, independentemente da presença de um macho lateral. Foram também observados 
resultados significativos na entrada e saída dos machos dos ninhos associados ao som, independentemente da existência ou ausência de um estímulo visual associado. No entanto, a sua presença levou a resultados marginalmente significativos, que poderiam demonstrar a importância deste tipo de estímulo na defesa territorial em Pomatoschistus pictus. Por sua vez, nas experiências com controlo sonoro (i.e. ruído branco) os resultados não foram significativamente relevantes, o que poderia estar relacionado com o número reduzido de observações neste tipo de tratamento. Verificamos ainda a possibilidade da existência de uma preferência do macho por um dos lados do aquário consoante o tipo de tratamento, porém os resultados obtidos não evidenciaram qualquer tipo de comportamento preferencial, apenas mostrando uma ligeira tendência para passar mais tempo do lado do som em vez do lado do silêncio ou do controlo acústico (ruído branco). Os resultados obtidos sugerem que os sons agonísticos são uma estratégia importante e eficaz na defesa territorial da espécie considerada, mas que há uma necessidade conjunta da presença de um outro macho no ninho para motivar esta postura agressiva.

Palavras-chave: sinais acústicos, comportamento agonístico, defesa territorial, sinais 'keep-out', experiências de playback, peixes teleósteos 


\section{Introduction}

In nature, resources such as those needed for breeding are scarce and variable in their quality. Hence, in order to have a chance to reproduce, individuals (typically males) will compete intensely over these limited resources (Huntingford \& Turner, 1987; Andersson, 1994). This competition is often solved through confrontations that frequently start with mutual assessment characterized by low-level agonistic displays and are only expected to escalate to overt aggression if asymmetries between individuals in fighting ability and resource ownership are small (Huntingford \& Turner, 1987; Briffa \& Sneddon, 2007).

Low-level aggressive behaviour involved in such contests is generally accompanied by sound production in a variety of different taxa (insects - Gerhardt \& Huber, 2002; fish - Ladich \& Myrberg, 2006; anurans - Davies \& Halliday, 1978; birds - Kort et al., 2009; and mammals Clutton-Brock \& Albon, 1979).Generally, these sounds are the result of the passage of air driving the vibration of a membrane such a larynx or a syrinx, as found in frogs, birds and mammals (Ladich, 2004). However, in fish, sound production mechanisms are different from the ones presented by other taxa (Amorim \& Neves, 2008), and are usually characterized by specialized sonic muscles associated with resonating structures or by other modified body structures. One of the main type of mechanisms comprises the swimbladder and sonic muscles (Demski et al., 1973; Connaughton et al., 2000; Parmentier et al., 2006a), where muscle contraction leads to the production of sound, as seen for example in gadids (Hawkins \& Amorim, 2000) and batrachoidids (Skoglund, 1961; Fine et al., 2001). Other mechanisms include the the collision of the jaw teeth, as registered in clownfish (Parmentier et al., 2007), or several other strategies involving different and specialized body structures such as pectoral mechanisms, as the vibration of the pectoral girdle in sculpins or plucking of enhanced fin 
tendons in croaking gouramis (Ladich \& Fine, 2006). In some cases, multiple tactics are used, as observed in catfishes, where both sonic muscle contraction against the swimbladder wall and fin stridulation lead to the production of different sounds (Amorim, 2006).

In fish, like in other animals, sound plays an important role in territorial defence and usually accompanies physical modifications (Ladich \& Myrberg, 2006; Amorim \& Neves, 2008; Kierl \& Johnston, 2010), functioning as a complement to visual displays such as colour alterations or aggressive visual displays, including fin erection or quivering (Ladich \& Myrberg, 2006). Experimental evidence from muted specimens and playbacks (Valinsky \& Rigley, 1981; Riggio, 1981; Ladich et al., 1992a; Ladich 1998), suggests that in agonistic scenarios sounds can reveal valuable information about the opponent without the need of overt confrontation and, thus, energy depletion or even mortality (Enquist \& Leimar, 1983; Ladich \& Myrberg, 2006; Amorim \& Neves, 2008). For example, body size is often advertised by the production of longer sounds with lower dominant frequencies that result from larger body structures (Myrberg et al., 1993; Lobel \& Mann, 1995; Connaughton et al., 2000). Other factors which are known to affect sound production and its characteristics are fish motivation during a confrontation (Amorim, 2006), which may be directly related with breeding (Fine, 1978; Connaughton \& Taylor, 1995), and steroid circulating levels that may lead to different patterns or repetitions of sonic muscles contraction or a more vigorous stridulation of the fins (Fine \& Pennypacker, 1986; Brantley et al., 1993; Connaughton et al., 1997; Remage-Healey \& Bass, 2006).

Though sound plays an extremely important role in some species communication and survival (Colleye et al., 2009), little is known about the role of acoustic signals in territorial defence in fish (Ladich \& Myrberg, 2006; Vasconcelos et al., 2010). In this study we aimed at examining 
the role of agonistic sounds in territorial defence using as a model a small marine vocal species, the painted goby (Pomatoschistus pictus) that depends on nest defence for reproduction (Amorim \& Neves, 2008). We experimentally examined whether males occupied more readily unoccupied nests (silent) or nests associated with a sound control (white noise) than 'occupied' nests. We mimicked nest occupation by the use of interactive playbacks where males received a sequence of conspecific agonistic sounds whenever they approached a nest within a body length. We checked for several reactions of the subject male to unoccupied and 'occupied' nests, including avoiding, exploring and entering the nests. We further checked for readiness in nest occupation in a similar-design experiment that further used additional visual stimuli that consisted of a male in a confinement aquarium placed next to the nest. We predicted that males would take longer to occupy nests associated with conspecific sound and especially when in the presence of a conspecific male.

\section{Material and methods}

\section{Study species}

Pomatoschistus pictus (Gobiidae, Teleostei) is a benthic fish that inhabits the coastal and shallow waters of the Eastern Atlantic and some areas of the Mediterranean, exhibiting a short life span of 2 years and up to $60 \mathrm{~mm}$ in length (Miller, 1986). Breeding season starts approximately in January until July, during which males display a very territorial behaviour, by building and protecting nests using small empty shells and other structures, and covering them with sand leaving only an opening (Miller, 1986; Bouchereau et al., 2003). Subsequently, females are attracted by male exhibitions, entering and laying their eggs on the top of the nest. These are then exclusively protected from predators by males until they hatch. 
During this phase, painted gobies exhibit territorial behaviour, emitting series of drums when conspecifics are near the nest, combining them with different visual displays such as quivering movements during frontal and lateral displays (Amorim \& Neves, 2008).

\section{Fish collection and maintenance}

We captured fish from January to April at Parede $\left(38^{\circ} 41^{\prime} \mathrm{N}, 9^{\circ} 21^{\prime} \mathrm{W}\right)$ during low spring tides, at night time, and with the help of hand nets and flashlights, and at Arrábida $\left(38^{\circ} 28^{\prime} \mathrm{N}\right.$, $\left.8^{\circ} 58^{\prime} \mathrm{W}\right)$ by scuba diving. In the laboratory we separated fish by gender and maintained them in stock 181 aquaria $(24 \times 24 \times 32 \mathrm{~cm})$ equipped with sand substrate and shelters. These were fed with a closed-circuit flow of artificial filtered sea water kept at $16{ }^{\circ} \mathrm{C}$ and were under a photoperiod of 12L:12D. We fed the fish daily ad libitum with chopped shrimps. All experimental procedures complied with Portuguese animal welfare laws, guidelines and policies.

\section{Experimental procedure}

351 glass experimental aquaria $(26 \times 51 \times 31 \mathrm{~cm})$ were divided in three equal compartments by clear or opaque partitions and presented the same substrate and water conditions as above. One subject was placed on the central division of the aquarium, $24 \mathrm{~h}$ prior the start of the test to allow it to become territorial. In each side compartments we placed one artificial PVC shelter $(5.5 \mathrm{~cm}$ length and $3 \mathrm{~cm}$ inner diameter) partially covered with sand and one custom made speaker (see below). The speaker was protected with a plastic net to prevent fish from exploring the equipment during each test. We also placed a net on both lateral walls of the experimental aquarium to reduce the possibility of fish interacting with its own reflection. 
We carried out two experiments that differed in the absence or presence of visual stimuli during the test period: 'playback only' and 'playback+visual'. In the 'playback only' experiment we presented a visual pre-stimulus that consisted in a male inside a small confinement aquarium $(8 \times 7 \times 22 \mathrm{~cm})$ provided with sand substrate, placed in each outer compartment close to a clear partition to increase visibility (Figure 1).

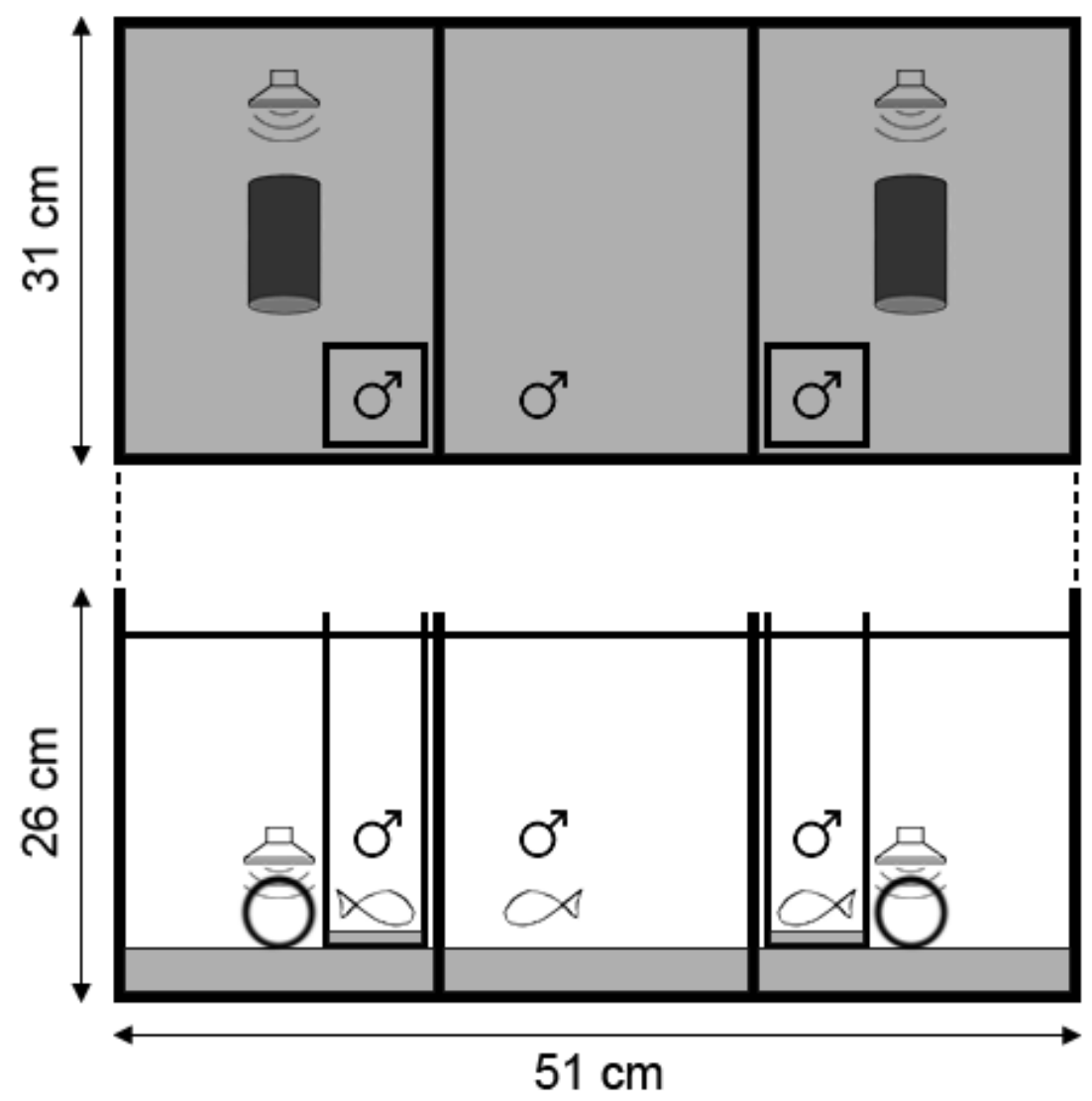

Figure 1 - Experimental setup during the visual pre-stimulus on the 'playback only' experiments. Lateral males were placed inside glass confinement aquariums $(8 \times 7 \times 22 \mathrm{~cm})$ between the nest and the side wall of the experimental aquarium $(26 \times 51 \times 31 \mathrm{~cm})$.

Stimulus males were matched in size, i.e. their standard length ratio was less than $10 \%$. The confinement aquaria were high enough to prevent the mixture of the water from stimuli males with the one from the subject male, thus hindering chemical communication between specimens. During the 'playback+visual' experiment the confinement glass containers were 
placed between the nest and the side wall of the experimental aquarium throughout the test period (Figure 2).

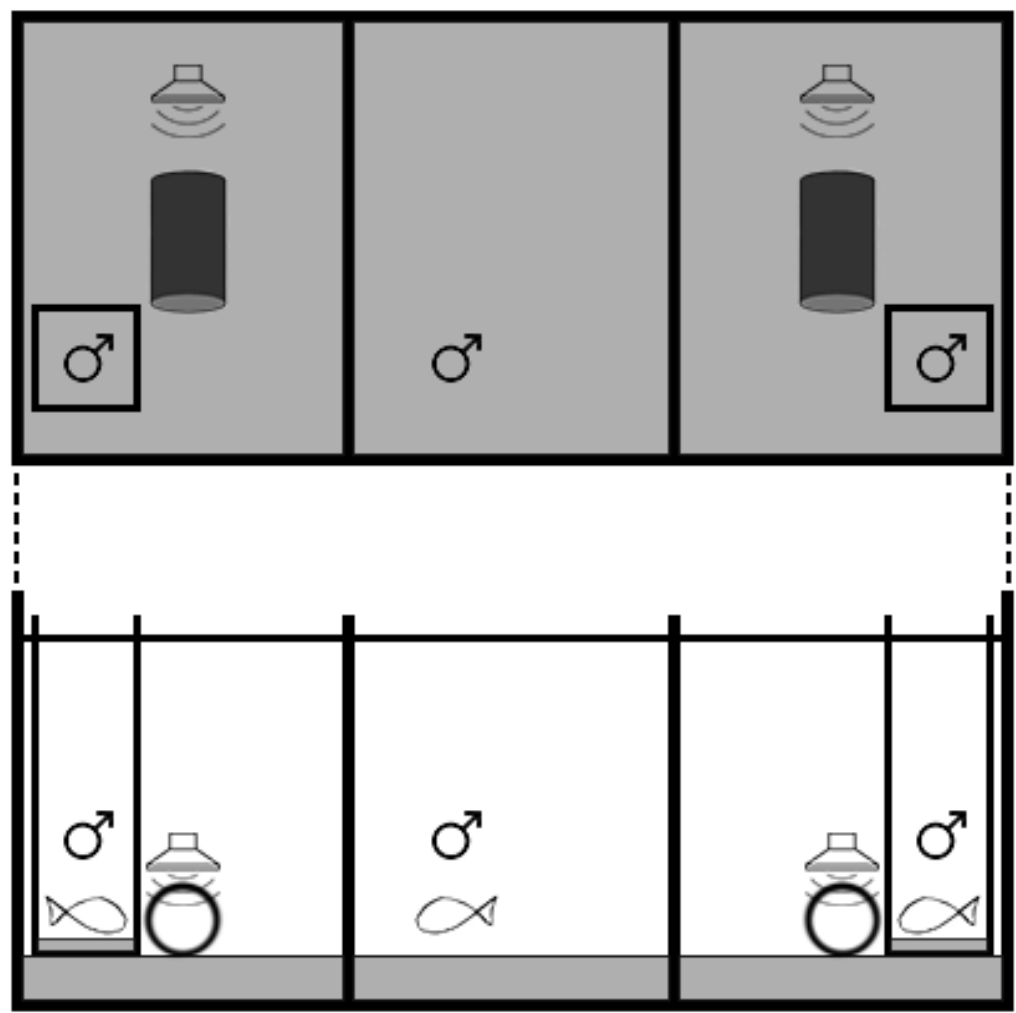

Figure 2 - Experimental setup during the test period on the 'playback+visual' experiments. Lateral males were placed inside glass confinement aquariums $(8 \times 7 \times 22 \mathrm{~cm})$ near the transparent partitions to increase visibility by the subject male placed in the central compartment of the experimental aquarium $(26 \times 51 \times 31 \mathrm{~cm})$.

\section{Part I: 'playback only'}

Circa 15 minutes after we turned off all the equipment in the room, we started recording and removed the opaque partitions, leaving the transparent partitions for a total of $10 \mathrm{~min}$, during which the subject fish in the central compartment had visual access to the lateral compartments. We finished this visual pre-stimulus by placing the opaque partitions back on and removing the lateral males, after which there was a silence period of 8 min followed by the emission of playback pre-stimulus with a total duration of 2 min. Afterwards all partitions 
were removed and the fish behaviour was observed for $5 \mathrm{~min}$, concluding a total $25 \mathrm{~min}$ of trial procedure.

Subject males were measured for standard length (SL) and weighted (W) after each test. A total of 12 gobies with SL ranging from 3.4 to $3.9 \mathrm{~cm}$ (mean \pm standard deviation [SD] = 3.7 $\pm 0.18 \mathrm{~cm})$ and $\mathrm{W}$ between 0.45 and $0.88 \mathrm{~g}(0.67 \pm 0.12 \mathrm{~g})$ were tested on the first part of this study.

\section{Part II: 'playback+visual'}

Similar to the previous experiment, circa 15 minutes after we turned off all the equipment the experiment started by keeping subject males in silence on the central compartment of the aquarium for $5 \mathrm{~min}$, while both opaque and transparent partitions were on. Subsequently, we started the emission of the playback pre-stimulus for $2 \mathrm{~min}$, followed by the removal of the plastic partitions and observation of the behaviour of the fish towards the nests and the visual stimuli. A total of 14 different males were tested with a SL ranging from 3.4 to $3.9 \mathrm{~cm}(3.7 \pm$ $0.16 \mathrm{~cm})$ and $\mathrm{W}$ between 0.48 and $0.88 \mathrm{~g}(0.7 \pm 0.13 \mathrm{~g})$.

\section{Playback treatment}

Trials started with a sound pre-stimulus in which fish were exposed to conspecific aggressive sounds and a control, white noise (WN) or silence from opposite sides of the tank. When sound was emitted on both sides of the aquarium, we insured that the playback of agonistic sounds and WN did not overlap to avoid interference and masking. The playback treatment (silence vs sound or WN vs sound) on each trial was randomly selected prior the start of the test, as was the assignment of each of the acoustic stimulus to each side of the aquarium. 
Aggressive sounds used on the playback treatments consisted of drums from three different males from our sound archive (2010) and each generated sequence comprised three different sounds from one male, i.e. there were three playback sequences. All files had the same length and acoustic energy, and spacing between sounds followed a typical pattern for this species observed in sound production during territorial defence. An identical number of WN files were created and shared the same properties (sound duration and sound intervals) as the drum sequences and were equalized to the same sound amplitude.

Playback experiments were performed using custom made speakers (Fonseca and Alves 2012), which are able to reproduce low frequency pulsed fish sounds with great accuracy such as the ones emitted by the painted goby (Figure 3).

a)

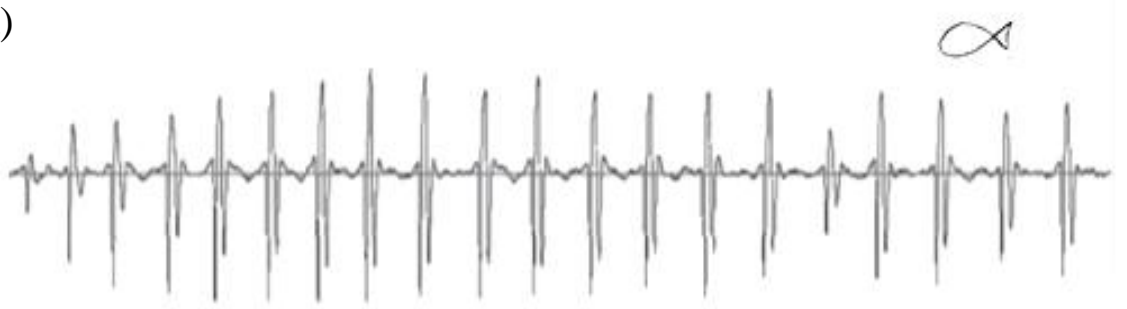

b)

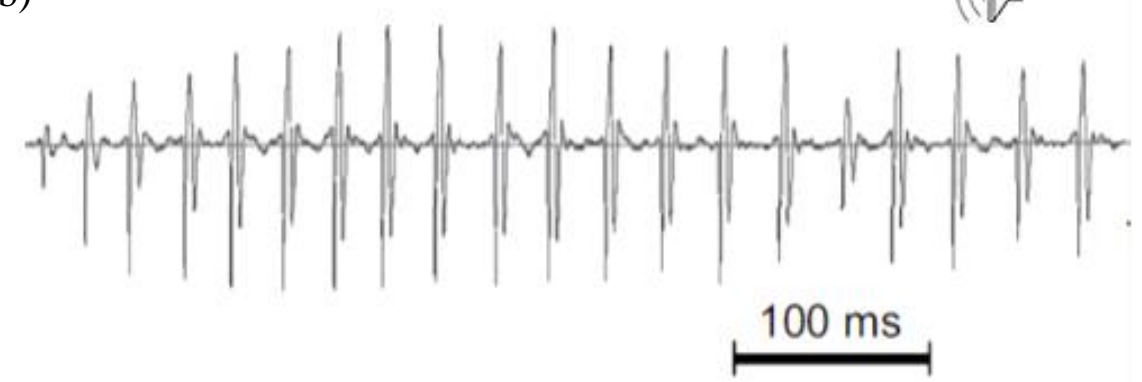

Figure 3 - Oscillogram of a drum sound produced by the painted goby (a) or played by the speaker (b). 
These were connected to a custom made amplifier (Fonseca and Alves 2012) fed through a D/A device (Edirol UA-25, Roland, Japan; 16 bit, 8 kHz) controlled by Adobe Audition 3.0 (Adobe Systems Inc., Mountain View, CA, USA), which allowed simultaneous two-channel recordings. The amplitude of the sound playback (drum or WN) was adjusted to mimic that of a painted goby male at 1-2 cm distance (c. $130 \mathrm{~dB}$ ) with a hydrophone (Brüel \& Kjær 8104, Brüel \& Kjær, Naerum, Denmark, sensitivity -205 dB re1V/ $\mu \mathrm{Pa})$. An additional hydrophone (High Tech 94 SSQ, High Tech Inc., Gulfport, MS, USA; sensitivity -165 dB re1V/ $\mu \mathrm{Pa}$; frequency response within $\pm 1 \mathrm{~dB}$ from $30 \mathrm{~Hz}$ to $6 \mathrm{kHz}$ ) was used on the playback experiments and kept on the central compartment of the experimental aquarium, to register any sound produced during trials.

Playback assays were interactive, i.e. every time the fish was within one body length (bl) from the nest we played the first three sounds of the correspondent playback treatment (sound or $\mathrm{WN})$.

\section{Behavioural recording and analysis}

Fish behaviour was recorded with a videocamera (Sony DCR-HC39, Sony, Tokyo, Japan) positioned $50 \mathrm{~cm}$ in front of the experimental tank and subsequently analysed with Etholog (v.2.2, Ottoni 2002). During the pre-stimuli, video recording captured the entire aquarium and then, during the test period, we focused on the tested male and its interactions with the nest or with the visual stimulus, when applicable. We registered the following behavioural parameters: approach, avoidance, explore, enter, and exit. Total time spent on each side of the aquarium and the first side explored by the fish were also registered. We only considered trials to be valid when the tested male approached at least one of the nests. 


\section{Statistical analyses}

Playback effects were analysed based on the different behaviours exhibited by the tested males, with and without visual stimulus. We carried out two-way ANOVAs to assess the influence of playback treatment (control vs sound) and experiment type: 'playback only' and 'playback+visual' on male nest-related behaviours: approach, avoidance, explore, enter and exit. We analysed the data separately for the playback treatments silence vs sound and WN vs sound.

We tested preference for sound or control sides of the experimental aquarium, with Wilcoxon non parametric tests where we considered the total time spent on each side during the test period. We further carried out Binomial tests to examine if fish first swam to the sound (or the control) side of the aquarium more often than expected by chance. The intention was to determine if there was a first preference based on the pre-stimuli playback treatment (silence vs sound or WN vs sound).

Statistical analyses were conducted with Statistica (10, Statsoft Inc., Tulsa, USA) and all data was transformed when necessary to meet assumptions of the used parametric tests. When there was no normality of the transformed data, non-parametric tests were used.

\section{Results}

During acoustic pre-stimulus subject males seemed not to react to sound playback while the plastic partitions were on. However, during the visual pre-stimulus, tested males focused on one of the sides and repeatedly, swam in up and down movements. Upon the removal of the 
partitions, the subject male readily moved to one side of the experimental aquarium, this behaviour being more obvious when there was an additional visual stimulus.

In the silence vs sound treatment fish made significantly more approaches to nests associated with sound than to silent nests but only when additional visual stimuli was present (Table 1, Fig. 4a).

Table 1 - Effects of playback treatment (PBK: silence vs sound) and experiment type (EXP: 'playback' only or 'playback+visual') on behaviours exhibited by subject males towards the nests - approach, avoidance, explore, enter and exit. Data were log-transformed when necessary to meet the ANOVA assumptions.

\begin{tabular}{llcc} 
Dependent variable & \multicolumn{1}{c}{ Factor } & $\boldsymbol{F}_{\mathbf{1 , 1 8}}$ & $\boldsymbol{p}$ \\
\hline Approach & PBK & 13.61 & 0.002 \\
& Exp & 10.90 & 0.004 \\
& PBK x Exp & 7.39 & 0.014 \\
\hline Log-Avoidance & PBK & 16.18 & 0.001 \\
& Exp & 0.07 & 0.791 \\
& PBK x Exp & 0.07 & 0.791 \\
\hline Log-Explore & PBK & 0.00 & 0.953 \\
& Exp & 2.65 & 0.121 \\
& PBK x Exp & 0.51 & 0.485 \\
\hline Log-Enter & PBK & 6.00 & 0.025 \\
& Exp & 0.65 & 0.432 \\
& PBK x Exp & 2.97 & 0.102 \\
\hline Log-Exit & PBK & 6.27 & 0.022 \\
& Exp & 1.67 & 0.212 \\
& PBK x Exp & 3.08 & 0.096
\end{tabular}

As a consequence males approached nests more often when in presence of additional visual stimuli. Interestingly, males avoided nests associated with agonistic drums more frequently than silent nests regardless of experiment type, i.e. 'playback only' and 'playback+visual' (Table 1, Figure 4b). We found no significant differences between the exploring behaviour towards silent or acoustic nests or between experiment types, but males entered and exited nests with sound more frequently than silent ones regardless of the absence/presence of visual 
stimuli (Table 1, Figures 4c, d). However, the interaction terms between the variables playback treatment and experiment type were marginally significant for both the behaviours enter and exit suggesting a tendency for males to repeatedly enter the acoustic nests more often than silent ones in the presence of a conspecific male (Table 1). This is supported by the observations during the trials, where we noticed fish would be more reactive when in the presence of a visual stimulus and, thus, interacted more with the nests.
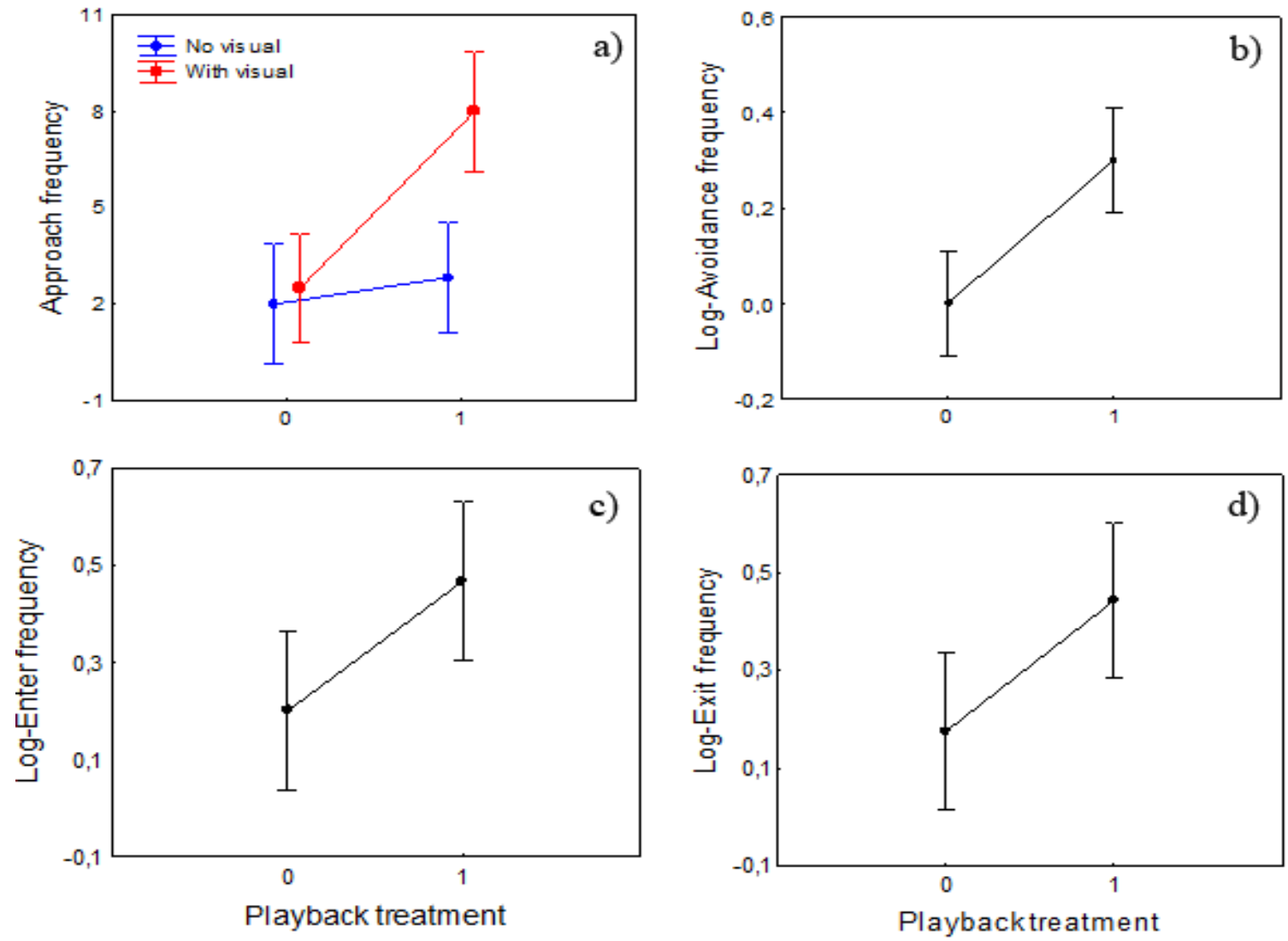

Figure 4 - Comparison of the different behaviours exhibited by the tested males towards the nest - approach, avoidance, enter and exit - according to different playback treatments (0: Silence; 1: Sound). Dots and error bars are means and $95 \%$ confidence intervals, respectively. All data was log-transformed when necessary.

Regarding WN vs sound treatment, there were no significant effects of the variables playback treatment and experiment type for the behaviours approach, explore, enter and exit performed by males towards the nest (Table 2). Although there was no playback treatment effect, we 
found a significant effect of experiment type as males avoided nests more often when there were no visual stimuli nearby (Table 2, Figure 5).

Table 2 - Effects of playback treatment (PBK: WN vs sound) and experiment type (Exp: 'playback' only or 'playback+visual') on behaviours exhibited by subject males towards the nests - approach, avoidance, explore, enter and exit. Data were log-transformed when necessary to meet the ANOVA assumptions.

\begin{tabular}{llll} 
Dependent variable & \multicolumn{1}{c}{ Factor } & $\boldsymbol{F}_{\mathbf{1 , 1 1}}$ & $\boldsymbol{p}$ \\
\hline Approach & PBK & 0.11 & 0.751 \\
& Exp & 0.49 & 0.499 \\
Avoidance & PBK x Exp & 0.18 & 0.683 \\
& PBK & 0.33 & 0.577 \\
\hline \multirow{2}{*}{ Explore } & Exp & 11.91 & 0.005 \\
\hline \multirow{2}{*}{ Enter } & PBK x Exp & 0.33 & 0.577 \\
\hline \multirow{2}{*}{ Log-Exit } & PBK & 0.00 & 1.000 \\
\hline \multirow{2}{*}{} & Exp & 0.63 & 0.445 \\
& PBK x Exp & 0.63 & 0.445 \\
& PBK & 0.30 & 0.592 \\
\hline & Exp & 1.83 & 0.203 \\
& PBK x Exp & 0.00 & 0.961 \\
& PBK & 0.67 & 0.430 \\
\hline
\end{tabular}

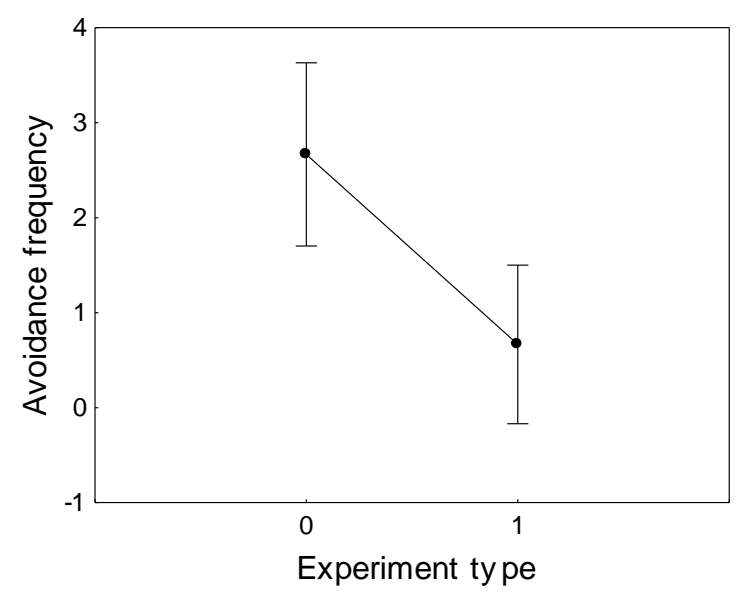

Figure 5 - Avoidance behaviour exhibited by subject males towards the nest according to different experiment types (0: playback only; 1: playback+visual). Dots and error bars are means and $95 \%$ confidence intervals, respectively. 
After the pre-stimuli, males swam to one side of the aquaria (sound vs control) at random, i.e. swimming towards the sound side was not different than expected by chance (Binomial test, $\mathrm{P}>0.05)$. Fish swam to the sound side 10 times out of 15 in the silence vs sound treatment and 6 out of 11 in the WN vs sound treatment. There was however a non-significant tendency for males to spend more time in the sound than in the silent side (Wilcoxon test, $\mathrm{N}=15, \mathrm{~T}=32.0$, $\mathrm{P}=0.11$; Figure $6 \mathrm{a}$ ) or the $\mathrm{WN}$ side (Wilcoxon test, $\mathrm{N}=11, \mathrm{~T}=14.0, \mathrm{P}=0.09$; Figure $6 \mathrm{~b}$ ).
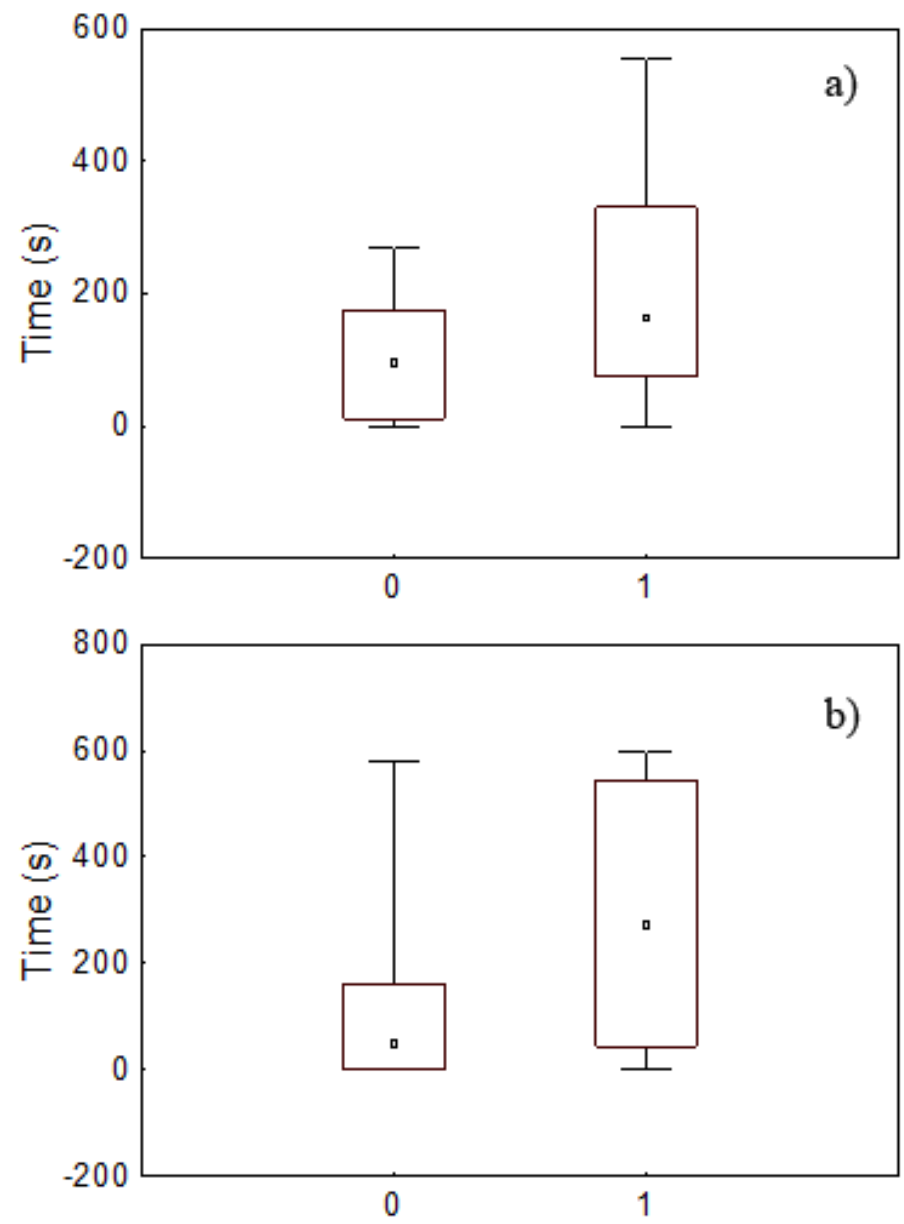

Playback treatment

Figure 6 - Comparison of the amount of time spent by tested males on each side of the aquarium according to playback treatment: (a) Silence vs sound and (b) WN vs sound treatment (0: Control; 1: Sound). Dots and boxes are medians and 25\%-75\% quartiles, respectively. Error bars are minimums and maximums. 


\section{Discussion}

In fish, sounds play an important role in territory acquisition and defence, as seen in multiple studies, allowing them to assess the condition of eventual competitors without the need of frontal confrontations. Besides being energetically costly, these could escalate to a series of interactions resulting in serious injuries or even death (Huntingford \& Turner, 1987). In this study we observed the effect of conspecific aggressive sound playback on the behaviour of subject painted goby males towards unoccupied nests. Additionally, we assessed the combined effect of sound playback with additional visual stimuli. On a first playback treatment (silence vs sound) we found that subject males would significantly approach nests associated with conspecific sounds more frequently than silent ones, and that they would interact more often with nests in the presence of an additional visual stimulus, a confined conspecific male. This pattern was also observed by Bertucci et al. (2010) where playback experiments combined with visual stimuli on a cichlid fish, Metriaclima zebra, showed that the subject specimen would stop swimming around the aquarium and focus on one of the side compartments when in the presence of a male separated by a transparent partition, actively interacting with the opponent and their own nest. In our study, though the results were marginally non-significant, subject males would also tend to enter and exit more often 'occupied' (acoustic) nests, implying an increase on their territorial stance. The opposite behaviour was also observed in 'playback only' experiments, where males would be less active suggesting that visual stimuli works as an additional motivation on territory defence complementing acoustic assessment of opponents (Bertucci et al., 2010).

Importantly, males avoided nests associated with agonistic sounds more frequently than silent nests regardless of the presence of the visual stimulus of a nearby male. This suggests that 
agonistic sounds have a significant role in territorial defence. According to Ladich \& Myrberg (2006) agonistic sounds can act as a 'keep-out' signal towards intruders (also see Vasconcelos et al., 2010). Playback experiments have shown that agonistic sounds can increase or decrease the aggressiveness of an opponent (Schwarz, 1974; Stout, 1975; Bertucci et al., 2010) or, as mentioned above, be used to indirectly evaluate the fighting condition of an adversary (Ladich, 1998). However, as subject painted goby males also entered and exited nests associated with agonistic sounds more frequently than silent nests, even in the presence of a nearby conspecific, it seems that sounds alone are not sufficient to prevent nest intrusion, but the active action of a territorial-holder is needed.

On the playback treatment that used white noise as a control we registered no significant effect for playback treatment for any of the behaviours towards the nest suggesting that males may not distinguish conspecific sound from white noise. The lack of significant differences in the reaction towards nests associated with agonistic sound or white noise should be seen with caution since they could be due to the low sample size $(\mathrm{N}=6)$. Although we believe that agonistic sounds are key to territorial defence in the studied species and in other fishes, additional experiments are needed to examine if any sound could function in territorial defence. For example white noise following the natural pulse patterns (durations and intervals) of agonistic sounds could be used in similar experiments. The white noise stimuli used in the present study contained the temporal pattern of the painted goby agonistic sounds which we believe is needed to elicit appropriate behavioural responses in the subject males. Consistently, it has been widely proposed that most of the information of fish sounds is contained in their temporal patterning (e.g. Winn, 1964; Amorim, 2006). 
In conclusion, we showed that agonistic sounds help but are per se insufficient to deter nest intrusions and that the additional visual stimulus of a conspecific nearby plays and important role in increasing the territorial behaviour in males. Additional experiments are required to test the significance of frequency and temporal patterns to deter territorial intrusion in fish. Also the role of sound emission rate and of sound duration should also be tested. The duration of agonistic drums and of sequences of drums have been shown to increase with painted goby male size suggesting it can provide valuable cues for male-male assessment (Amorim \& Neves, 2008).

\section{Acknowledgments}

First, I would like to thank my supervisors, Dr. Maria Clara Amorim and Prof. Dr. Paulo Fonseca for the opportunity to work and develop this study on such a personal and professionally enriching team and environment. Thank you for all the help, advice, extremely valuable criticism and corrections during the elaboration of this dissertation, and for every piece of knowledge shared over this period.

I would also like to thank Sílvia Pedroso, Joana de Melo Jordão and Daniela Pio. More than workplace colleagues, they turned out to be a great source of inspiration and support, becoming really important friends in whom I could (and can) always rely on when needed, whether it was with work related or personal subjects. Thank you three for every single great moment both in the office and in the field, the laughs, the immense amounts of patience (!), coffees, electrical shocks and, of course, for all the shared knowledge and experiences, and for all the help provided throughout the year. I truly believe I grew up a lot just by getting to know you. 
Carlotta Conti, Daniel Alves, Manuel Caiano, thank you, respectively, for making many of the moments a lot easier to get through, for all the shared insights and for all the help during the experimental assays of this study.

Diogo Gonçalves, Diogo Lorena, Joana Pereira, Laíse Gomes, for being my support throughout the year and for being there for me. By now you probably know as much of fish behaviour and their biology as I do. Thank you so much for the constant motivational words and for the patience during some extensive hearing sessions while I just babbled over and over again, criticizing fish and rambling about some less positive and productive days at work, for all the laughs and general great and memorable moments all year round.

Iliona Wolfowicz, João Cipriano, Fernando Pérsio, Cláudia Aguiar and Maciej Czajka, because even if you are miles away, and we do not speak on a daily basis, all five of you are important each on its own, and were a valuable source of motivation and positiveness not only now, but ever since I met you. Thank you for making me laugh, think and, especially, grow, over the years and I really hope I can count on you for years to come.

Ângela Motaco, André Basílio, Dulce Oliveira and João Guilherme, because in one way or another you are truly special friends from which I have learnt a lot (and still do), and were present throughout the year and development of this thesis, always being supportive and present when needed. Thank you!

Lastly, I would like to acknowledge and thank my parents, Maria Augusta Soares and Jorge Urbano Pereira, for all the intensive support during my life and the constant investment on my scientific career, especially over the past two years where I have been able to go through some life changing decisions. It is truly important to have you two by my side, helping, understanding and sharing your knowledge with me every day. 
This research was funded by the Science and Technology Foundation, Portugal (project PTDC/MAR/68868/2006, pluriannual program UI\&D 331/94 and UI\&D 329).

\section{References}

- ReferencesAmorim, M. C. P., 2006. Diversity of sound production in fish. In: Communication in fishes, Vol. 1 (Ladich F., Collin S. P., Moller P., Kapoor B. G., eds). Science Publishers, Enfield, U.S.A.

- $\quad$ Amorim, M. C. P. \& Neves, A. S. M., 2008. Male painted gobies (Pomatoschistus pictus) vocalise to defend territories. Behaviour 145, 1065-1083.

- Andersson, M., 1994. Sexual Selection, Princeton, New Jersey: Princeton University Press.

- $\quad$ Bertucci, F., Beauchaud, M., Attia, J., Mathevon, N., 2010. Sounds modulate males' aggressiveness in a cichlid fish. Ethology 116, 1179-1188.

- Bouchereau, J. L., Houder, V., Marques, A., Rebelo, J. E., 2003. A new distribution record and the reproductive strategy of Pomatoschistus pictus adriaticus (Pisces: Gobiidae) in the Mediterranean Sea. Journal of the Marine Biological Association of the United Kingdom 83, 1157-1161.

- $\quad$ Brantley, R. K., Marchaterre, M. A., Bass, A. H., 1993. Androgen effects on vocal muscle structure in a teleost fish with inter- and intra-sexual dimorphism. Journal of Morphology 216, 305-318.

- $\quad$ Briffa, M. \& Sneddon, L. U., 2007. Physiological constraints on contest behaviour. Functional Ecology 21, 627-637.

- Clutton-Brock, T. H. \& Albon, S. D., 1979. The roaring of red deer and the evolution of honest advertisement. Behaviour 69, 145-169.

- Colleye, O., Frédérich, B., Vandewalle, P., Casadevall, M., Parmentier, E., 2009. Agonistic sounds in the skunk clownfish Amphiprion akallopisos: size-related variation in acoustic features. Journal of Fish Biology 75, 908-916.

- Connaughton, M. A., Taylor, M. H., 1995. Seasonal and daily cycles in sound production associated with spawning in the weakfish, Cynoscion regalis. Environmental Biology of Fishes 42, 233-240.

- Connaughton, M. A., Fine, M. L., Taylor, M. H., 1997. The effects of seasonal hypertrophy and atrophy on fiber morphology, metabolic substrate concentration and sound characteristics of the weakfish sonic muscle. Journal of Experimental Biology 200, 2449-2457.

- Connaughton, M. A., Taylor, M. H., Fine, M. L., 2000. Effects of fish size and temperature on weakfish disturbance calls: implications for the mechanism of sound generation. Journal of Experimental Biology 203, 1503-1512.

- Davies, N. B. \& Halliday, T. R., 1978. Deep croaks and fight assessment in toads Bufo bufo. Nature 274, 683-685. 
- Demski, L. S., Gerald, J. W., Popper, A. N., 1973. Central and peripheral mechanisms of teleost sound production. American Zoologist 13, 1141-1167.

- Enquist, M. \& Leimar, L., 1983. Evolution of fighting behaviour: decision rules and assessment of relative strength. Journal of Theoretical Biology 102, 387-410.

- $\quad$ Fine, M. L., 1978. Seasonal and geographical variation of the mating call of the oyster toadfish Opsanus tau L. Oecologia 36, 45-57.

- $\quad$ Fine, M. L. \& Pennyacker, K. R., 1986. Hormonal basis for sexual dimorphism of the sound-producing apparatus of the oyster toadfish. Experimental Neurology 92, 289-298.

- $\quad$ Fine, M. L., Malloy, K. L., King, C. B., Mitchell, S. L., Cameron, T. M., 2001. Movement and sound generation by the toadfish swimbladder. Journal of Comparative Physiology A 187, 371-379.

- Fonseca, P. J. \& Alves, J. M., 2012. A new concept in underwater high fidelity low frequency sound generation. Review of Scientific Instruments 83, 055007

- Gerhardt, H. C. \& Huber, F., 2002. Acoustic communication in insects and anurans: common problems and diverse solutions. Chicago and London: The University of Chicago Press.

- Hawkins, A. D. \& Amorim, M. C. P., 2000. Spawning sounds of the male haddock, Melanogrammus aeglefinus. Environmental Biology of Fishes 59, 29-41.

- $\quad$ Huntingford, F. \& Turner, A. K., 1987. Animal Conflict. London: Chapman \& Hall.

- $\quad$ Kierl, N. C. \& Johnston, C. E., 2010. Sound production in the pygmy sculpin Cottus paulus (Cottidae) during courtship and agonistic behaviours. Journal of Fish Biology 77, 1268-1281.

- $\quad$ de Kort, S. R., Eldermire, E. R. B., Cramer, E. R. A., Vehrencamp, S. L., 2009. The deterrent effect of bird song in territory defense. Behavioral Ecology 20, 200-206.

- $\quad$ Ladich, F., 1998. Sound characteristics and outcome of contests in male croaking gouramis (Teleostei). Ethology 104, 517-529.

- Ladich, F., 2004. Sound production and acoustic communication. In: The senses of fishes. Adaptations for the Reception of Natural Stimuli (van der Emde, G., Mogdans, J., Kapoor, B. G., eds). New Delhi: Narosa, pp. 210-230.

- Ladich, F. \& Fine, M. L., 2006. Sound-generating mechanisms in fishes: a unique diversity in vertebrates. In: Communication in fishes, Vol 1 (Ladich F., Collin S. P., Moller P., Kapoor B. G., eds). Science Publishers, Enfield, U.S.A.

- Ladich, F. \& Myrberg, A. A., 2006. Agonistic behavior and acoustic communication. In: Communication in fishes, Vol 1 (Ladich, F., Collin, S. P., Moller, P., Kapoor, B. G., eds). Science Publishers, Enfield, U.S.A., pp. 122-148.

- $\quad$ Ladich, F., Bischof, C., Schleinzer, G., Fuchs, A., 1992a. Intra- and interspecific differences in agonistic vocalization in croaking gouramis (Genus: Trichopsis, Anabantoidei, Teleostei). Bioacoustics 4, 131141.

- Lobel, P. S. \& Mann, D., 1995. Spawning sounds of the damselfish, Dascyllus albisella (Pomacentridae), and relationship to male size. Bioacoustics 6, 187-198. 
- Miller, P. J., 1986. Gobidae. In: Fish of the North-eastern Atlantic and Mediterranean, Vol. III (Whitehead, P. J. P., Bauchot, M. L., Hureau, J. C., Nielsen, J., Tortonese, E., eds), pp. 1019-1985. UNESCO Paris.

- Myrberg, A. A., Ha, S. J., Shamblott, H., 1993. The sounds of bicolor damselfish (Pomacentrus partitus): Predictors of body size and a spectral basis for individual recognition and assessment. Journal of the Acoustical Society of America 94, 3067-3070.

- Ottoni, E. B., 2000. EthoLog 2.2: a tool for the transcription and timing of behavior observation sessions. Behavior Research Methods, Instruments, \& Computers 32, 446-449.

- Parmentier, E., Lagardère, J. P., Braquenier, J. B., Vandewalle, P., Fine, M. L., 2006a. Sound production mechanism in carapid fish: first example with a slow sonic muscle. Journal of Experimental Biology 209, 2952-2960.

- Parmentier, E., Colleye, O., Fine, M. L., Frédérich, B., Vandewalle, P., Herrel, A., 2007. Sound production in the clownfish Amphiprion clarkia. Science 316, 1006.

- Remage-Healey, L., Bass, A. H., 2006. A rapid neuromodulatory role for steroid hormones in the control of reproductive behavior. Brain Research 1126, 27-35.

- Riggio, R., 1981. Acoustical correlates of aggression in the bicolor damselfish, Pomacentrus partitus. MSc thesis, University of Miami, Miami, FL.

- Schwarz, A., 1974. Sound production and associated behaviour in a cichlid fish, Cichlasoma centrarchus. I. Male-male interactions. Z. Tierpsychol. 35, 147-156.

- Skoglund, C. R., 1961. Functional analysis of swimbladder muscles engaged in sound production of the toadfish. Journal of Biophysical and Biochemical Cytology 10 (Suppl): 187-200.

- Stout, J. F., 1975. Sound communication during the reproductive behavior of Notropis analostanus. American Midland Naturalist 94, 296-325.

- Valinsky, W. \& Rigley, L., 1981. Function of sound production by the skunk loach Botia horae (Pisces, Cobitidae). Z. Tierpsychol. 55, 161-172.

- Vasconcelos, R. O., Simões, J. M., Almada, V. C., Fonseca, P. J., Amorim, M. C. P., 2010. Vocal behaviour during territorial intrusions in the Lusitanian toadfish: boatwhistles also function as territorial 'keep-out' signals. Ethology 116, 155-165.

- Winn, H. E., 1964. The biological significance of fish sounds. In: Marine Bio-Acoustics. W.N. Tavolga (ed.). Pergamon Press, New York, NY, pp. 213-231. 